\title{
'Soviet' in teachers' memories and professional beliefs in Kazakhstan: points for reflection for reformers, international consultants and practitioners
}

Olena Fimyar, Kairat Kurakbayev

Graduate School of Education

\section{Abstract}

This paper is a part of a three-year study, 'Internationalisation and reform of secondary schooling in Kazakhstan', jointly conducted by an international team of UK- and Kazakhstan-based researchers in 2012-2014. The study was conceived as a mechanism to support education reform in the country. This was achieved through reconstructing the education policy narrative of the last two decades and understanding the effects of the newly established Nazarbayev Intellectual Schools and the Centres of Excellence in-service professional development programme on the larger system. While the focus of the study was on Kazakhstan's educational present, the references to the previous system of education, which was often referred to as Soviet, traditional, but also successful, fundamental and the best in the world, were numerous. These continuous references to the past prompted the authors of this paper to address the questions: What memories and practices of Soviet education are still dominant in the field of education in Kazakhstan? How do these beliefs continue to shape educational debate in the country? In support of its argument, the paper draws on the literature on Soviet schooling and contemporary education reform, interview data with national and international teachers in Kazakhstan, and field observations. The resultant narrative, which brings together the analysis of educational change and changes in teachers' beliefs, may appeal to many involved in the construction of the contemporary reform agenda.

\begin{tabular}{ll}
$\begin{array}{l}\text { Original } \\
\text { language } \\
\text { Pages (from-to) } \\
\text { Number of } \\
\text { pages }\end{array}$ & English \\
& $86-103$ \\
Journal & 18 \\
Volume & $\begin{array}{l}\text { International Journal of Qualitative } \\
\text { Studies in Education }\end{array}$ \\
Issue number & 29 \\
State & 1 \\
\hline
\end{tabular}

Fimyar, O., \& Kurakbayev, K. (2016). 'Soviet' in teachers' memories and professional beliefs in Kazakhstan: points for reflection for reformers, international consultants and practitioners. International Journal of Qualitative Studies in Education, 29(1), 86-103. DOI: 10.1080/09518398.2015.1017850 